\title{
EXPERIENTIAL LEARNING: TOOL FOR JOYFUL LEARNING
}

\author{
Prashant Thote ${ }^{*}{ }^{凶}$, Gowri. S 2 \\ 1,2 Gyanodaya Vidya Mandir, India
}

DOI: https://doi.org/10.29121/granthaalayah.v8.i5.2020.88

Article Type: Research Article

Article Citation: Prashant Thote, and Gowri. S. (2020).

EXPERIENTIAL LEARNING: TOOL FOR JOYFUL LEARNING.

International Journal of Research GRANTHAALAYAH, 8(5), 100-107. https://doi.org/10.29121/granthaa layah.v8.i5.2020.88

Received Date: 13 May 2020

Accepted Date: 28 May 2020

Keywords:

Art Integrated Learning

Mathematics

Creativity

School

Evaluation

\begin{abstract}
In this paper attempt is made to investigate the impact of Art Integrated Learning on the academic achievement of grade 5 students in mathematics. Total 80 students participate in the study, 40 students in the Experimental group and 40 in the control group. Two different Art Integrated Learning activities are designed for experimental group. The same teacher teaches both the experimental and the control group. The teacher uses Art Integrated Learning methods for teaching grade 5 students and traditional chalk and talk method for control group students. At the end of each unit (four tests), Mathematical Achievement Test (MAT) is administrated to determine the difference between the knowledge of the students in the experimental group and the control group. The result of all four tests is consistent. Art Integrated Learning has improved the academic achievement of students of experiential group.
\end{abstract}

\section{INTRODUCTION}

"If a child cannot learn the way we teach, maybe we should teach the way they learn" - Ignacto Esizalq

Central Board of Secondary Education has taken initiative to inculcate Art Integrated Learning as an approach to teaching, in which the arts leverage learning in other core subjects of school curriculum, such as science, social science, and mathematics. Art Integrated Learning is a methodology of teaching through which, students build and establish understanding towards an art form. Students participate in innovative process which connects various art forms and core subjects in school curriculum. It achieves the most evolving learning objectives in both. Art Integrated Learning is an approach to teaching.

Art Integration is done for the purpose of education. Survival stories are performed through songs and dance in ancient civilization in order to teach the survival skills, explain the weather and to share their beliefs. Art Integrated Learning is already an innate process of learning. Art Integrated Learning method is not new and has already been established through many researches as being effective teaching-learning methodology to all grades, gender and socio-economic based programmes. Education must involve young learners to engage themselves in learning. Effective teacher is just a facilitator of knowledge and not dictators. To align with the standards of effective teaching,

(C) 2020 The Author(s). This is an open access article distributed under the terms of the Creative Commons Attribution License, which permits unrestricted use, distribution, and reproduction in any medium, provided the original author and source are credited. 
Art Integrated Learning creates class-room environment that are engaging. Art Integrated Learning process of reciprocal engagement enhances the level of thinking of a teacher through planning lesson and for students through participation in the lessons. If teachers are interested in creating lessons that have multi-sensory approach to Teaching-Learning, the learners are more likely to be engaged and be active. Teaching-Learning must stimulate emotions with academics.

The joy and the content provided in the class-room make learners to actively participate and give them a pleasant experience. Joyful learning improves information transformation and storage in brain. The advanced learning happens when class-room experience is joyful and relevant to the students' life, interest and experience. The strong positive emotions enhance the level of learning.

Learning process is negatively attached with stress, boredom, confusion, low motivation and anxiety. When stress is activated in the class-room situation, brain automatically filter and limits the information flow to higher cognitive level and the learning process come to a halt.

When learners use their individual senses of hearing, touch, taste, vision and smell as a primary means of learning the information received is stored for a longer period. A teacher should create an environment, with low anxiety level. Class-room situation is usually stressful when concepts are overtly abstract in nature and irrelevant to the students. A teacher can reduce class-room stress by making lesson more interesting and motivating. Actually, students should be able to answer the question, "Why are we learning about this?" at any point of the lesson.

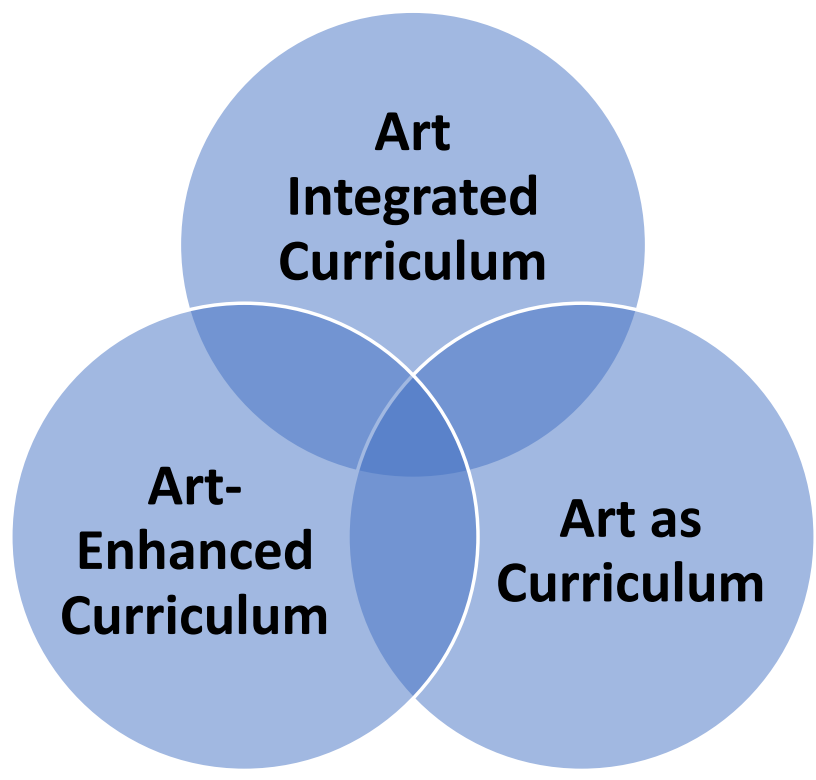

Figure 1: Art Integrated Learning

When lesson/ blocks of lessons are full of facts to memorized, students will feel less stress, as students master the tool for participating in Art Integrated Learning. Learning cannot be operated without fun. When students actively partake in the learning process there is a higher level of cognition connection between the students and the teachers. A suitable learning environment with proper learning sequence is also essential for the students.

H1- The experimental group students (EG) are taught by using Art Integrated Learning to achieve better result in Mathematics Achievement Test (MAT)

H2- The students of experimental group will perform better in art education with better achievement in MAT as compared to the control group.

\section{METHODS}

Research Design: Descriptive and casual experiment design is applied.

Sample: The targeted population of the study is grade 5 students. Total 80 students participated in the study, 40 in the control group and 40 in the experimental group. 
Table 1: Structure of Sample

\begin{tabular}{|c|c|c|}
\hline Group & M & $\%$ \\
\hline EG & 40 & 50 \\
\hline CG & 40 & 50 \\
\hline Total & 80 & $100 \%$ \\
\hline
\end{tabular}

Tool: The researcher has conducted four MAT tests.

1) Sensitivity of MAT is checked by Ferguson's Co-efficient Test

2) The objectivity of the execution is ensured by clear and unambiguous successions, questions and problems. Students of the control group and the experimental group have completed the same exercise.

3) The reliability of test is verified using Cronbach's co-efficient alpha.

4) The validity of content is verified by two experts and construct validity is determined by factor analysis.

For the better conduction of the experiment, the researcher compares the experimental group and the control group based on the marks obtained in art education and mathematics of grade IV (final grade).

During pedagogical Art Integrated Learning experiment same teacher teaches the students of the control group and the experimental group. Topics such as equation, in-equation, power and perimeters are taught. The teacher uses traditional chalk and talk methods for teaching the control group and while teaching the experimental group Art Integrated Learning is used. Art Integrated Learning activities such as artistic balance-was integrated into equations, artistic- imbalance into in-equations, rhythms into power and articulating space into perimeter. Teacher prepares detailed lesson plans. The students appear MAT after the completion of each topic. Thus they undertake a total of four tests. Tests are prepared well in advance and structured using Blooms Taxonomy. The experiment is carried out during regular school lessons.

\section{RESULT AND DISCUSSIONS}

In order to co-ordinate the knowledge of the experimental group and the control group, the researcher considers the marks of art education and mathematics of previous year.

Table 2: Average score of experimental group and control group in grade IV

\begin{tabular}{|c|c|c|c|c|}
\hline & Group & $\mathrm{N}$ & $\mathrm{M}$ & $\mathrm{SD}$ \\
\hline \multirow{2}{*}{ Art Education } & EG & 40 & 4.42 & 0.78 \\
\cline { 2 - 5 } & CG & 40 & 4.62 & 0.57 \\
\hline Mathematics & EG & 40 & 3.86 & 1.03 \\
\cline { 2 - 5 } & CG & 40 & 3.97 & 0.99 \\
\hline
\end{tabular}

Result of the study shows that the average score of students in the control group and the experimental group in art education is different but in Mathematics it is same. The experimental group achieve high average score $(\mathrm{M}=4.42)$ in art education than the control group $(\mathrm{M}=4.02)$. Both groups score higher marks in art education than Mathematics.

Table 3: T - Test for independent

\begin{tabular}{|c|c|c|c|c|c|c|}
\hline & Group & $\mathrm{M}$ & $\mathrm{p}$ & $\mathrm{t}$ & $\mathrm{df}$ & $\mathrm{b}$ \\
\hline \multirow{2}{*}{ Art Education } & $\mathrm{CG}$ & 11.86 & 0.001 & -2.139 & 179 & 0.001 \\
\cline { 2 - 3 } & $\mathrm{EG}$ & & & & & \\
\hline Mathematics & $\mathrm{CG}$ & 0.422 & 0.52 & -0.812 & 210 & 0.52 \\
\cline { 2 - 3 } & $\mathrm{EG}$ & & & & & \\
\hline
\end{tabular}

The result of the study reveals that T-test for independent sample shows that there is statistical difference between experimental group and the control group in last year's Art education marks $(F=-2.139, \mathrm{P}=20.001)$. On comparing the experimental group and the control group the value of marks of Mathematics, is not significantly important. 


\subsection{ART INTEGRATED LEARNING EXPERIMENTAL RESULT}

Table 4: The criterion

\begin{tabular}{|c|c|}
\hline Points & Marks \\
\hline $0-6.49$ & 1 \\
\hline $6.49-8.49$ & 2 \\
\hline $8.50-10.49$ & 3 \\
\hline $10.50-11.49$ & 4 \\
\hline $11.50-12$ & 5 \\
\hline
\end{tabular}

The researcher marks student's achievement in MAT score from zero to twelve level points to get more precise results.

\section{Hypothesis $\left(\mathrm{H}_{0} 1\right)$}

Experimental group students are taught by using Art Integrated Learning. They will score higher result in Mathematics Achievement Test (MAT) than their counter part. The control group is taught using conventional methods of teaching.

Table 5: Mathematics Achievement Test (MAT) Score

\begin{tabular}{|c|c|c|c|c|}
\hline MAT Education & Group & $\mathrm{N}$ & $\mathrm{M}$ & $\mathrm{SD}$ \\
\hline \multirow{3}{*}{ Equation } & $\mathrm{EG}$ & 40 & 9.54 & 2.08 \\
\cline { 2 - 5 } & $\mathrm{CG}$ & 40 & 6.73 & 3.22 \\
\hline \multirow{3}{*}{ In equation } & EG & 40 & 9.33 & 2.33 \\
\cline { 2 - 5 } & $\mathrm{CG}$ & 40 & 6.72 & 2.67 \\
\hline \multirow{2}{*}{ Power } & $\mathrm{EG}$ & 40 & 9.32 & 2.52 \\
\cline { 2 - 5 } & $\mathrm{CG}$ & 40 & 6.63 & 2.68 \\
\hline & $\mathrm{EG}$ & 40 & 9.93 & 2.07 \\
\cline { 2 - 5 } & $\mathrm{CG}$ & 40 & 8.42 & 2.56 \\
\hline
\end{tabular}

The result of the study reveals the descriptive statistics of all four MAT tests of both experimental group and the control group $(\mathrm{N}=80)$. The mean of condition equation for the experimental group is 9.54 and for the control group is 6.73. The students of the experimental group achieve better result in MAT than their counter parts (control group). The students of the experimental group perform better in other three MAT tests also.

Table 6: T-test in Independent sample

\begin{tabular}{|c|c|c|c|}
\hline MAT & $\mathrm{t}$ & $\mathrm{df}$ & $\mathrm{p}$ \\
\hline Equation & -6.77 & 75.83 & 0.000 \\
\hline In equation & -7.45 & 98 & 0.000 \\
\hline Powers & -7.46 & 98 & 0.000 \\
\hline Perimeter & -7.71 & 98 & 0.001 \\
\hline
\end{tabular}

Table 7: Levene's -test for equality variance

\begin{tabular}{|c|c|c|c|c|}
\hline MAT & $\mathrm{F}$ & $\mathrm{df}_{1}$ & $\mathrm{df}_{2}$ & $\mathrm{p}$ \\
\hline Equation & 20.557 & 1 & 78 & 0.000 \\
\hline In equation & 0.309 & 1 & 78 & 0.568 \\
\hline Powers & 0.125 & 1 & 78 & 0.686 \\
\hline Perimeter & 2.639 & 1 & 78 & 0.085 \\
\hline
\end{tabular}

Table 8: Multivariate Test: Efficiency of Art Integrated Learning

\begin{tabular}{|c|c|c|c|c|c|}
\hline & Value & $\mathrm{f}$ & $\mathrm{df}$ (hypothesis) & df(error) & $\mathrm{p}$ \\
\hline Wilk's Lambda & 0.647 & 26.27 & 4.00 & 200 & 0.000 \\
\hline
\end{tabular}


The result of multivariate test reveals that, results are statistically significant for the first hypothesis. It means null hypothesis is rejected. The experimental group of students has statistically significant difference in relationship to their academic performance. It supports the first hypothesis. The multivariate test Wilk's Lambda exhibits that there is no considerable difference between both the experimental group and the control group. The result of multivariate test indicates that there is statistically significantly difference in academic performance $\mathrm{f}(4$. 205) $\mathrm{p}<0.005$, Wilk's $\mathrm{A}=0.647$

Table 9: Test Score of Mathematical Topic

\begin{tabular}{|c|c|c|c|c|}
\hline Source & Variables & $\mathrm{f}$ & $\mathrm{df}$ & $\mathrm{p}$ \\
\hline \multirow{3}{*}{ Co- Ex } & Equation & 45.68 & 1 & 0.000 \\
\cline { 2 - 5 } & In equation & 85.32 & 1 & 0.000 \\
\cline { 2 - 5 } & Power & 85.78 & 1 & 0.000 \\
\cline { 2 - 5 } & Perimeter & 22.87 & 1 & 0.000 \\
\hline
\end{tabular}

Result from Table-9 shows that Art Integrated Learning activities for Mathematics have significant effect on research units in mathematics of grade five, Equation $f(i=208)=43.72, p<0.0005$, in-equation $f(1.205)$ $=55.32<0.005$, power (f 1.208) $=55.08, \mathrm{p}<0.005$; perimeter $(\mathrm{f}=1.208)=22.30, \mathrm{p}<0.0005$.

The researcher observes that there is a great difference in Art Integrated Learning on Mathematics between the experimental group and the control group in the topic power and a little difference in perimeter. It may be due to small visuals used in the topic.

\section{Hypothesis Ho2}

The students of the experimental group perform better in Art Education with better achievement in MAT as compared to the control groups.

Table 10: Descriptive statistics of sample

\begin{tabular}{|c|c|c|c|c|}
\hline Test & Groups & $\mathrm{M}$ & $\mathrm{SD}$ & $\mathrm{N}$ \\
\hline \multirow{3}{*}{ Equations } & EG & 7.73 & 2.78 & 40 \\
\cline { 2 - 5 } & $\mathrm{CG}$ & 9.18 & 1.77 & 40 \\
\cline { 2 - 5 } & Total & 8.80 & 2.47 & 80 \\
\hline \multirow{3}{*}{ In equations } & EG & 7.11 & 1.86 & 40 \\
\cline { 2 - 5 } & $\mathrm{CG}$ & 9.60 & 2.26 & 40 \\
\cline { 2 - 5 } & Total & 8.44 & 2.48 & 80 \\
\hline \multirow{3}{*}{ Perimer } & EG & 6.81 & 2.39 & 40 \\
\cline { 2 - 5 } & $\mathrm{CG}$ & 9.57 & 2.18 & 40 \\
\cline { 2 - 5 } & Total & 8.28 & 2.76 & 80 \\
\hline & EG & 8.65 & 2.42 & 40 \\
\cline { 2 - 5 } & CG & 9.99 & 2.08 & 40 \\
\cline { 2 - 5 } & Total & 9.37 & 32.31 & 80 \\
\hline
\end{tabular}

Result of the study (Table - 10) shows that descriptive statistics in MAT of the experimental group and the control group students with Art Integrated Learning for grade five are $\mathrm{N}=40$ in EG and N=40 in CG. The above mean for education is found to be 7.73 for experimental group and 9.18 for the control group. Students in the experimental group perform better in MAT as compared to the control group. Experimental group perform much better as compared to Control group in all four test in MAT.

Table 11: Multivariate Test

\begin{tabular}{|c|c|c|c|c|c|}
\hline Wilk's Lambda & Value & $\mathrm{f}$ & df(hypothesis) & df(error) & P \\
\hline & 0.645 & 16.143 & 4.000 & 121.000 & 0.0001 \\
\hline
\end{tabular}


Multivariate test (Table -11) reveals that the results are statistically significant for hypothesis two. Mean of hypothesis is discarded. The study states that the experimental group and the control group are statistically different in terms of academic performance. This supports hypothesis two.

The null hypothesis of multivariate test Wilk's Lambda shows that there is no difference between two groups, but, there is statistical difference in the effect of Art Integrated Learning $f(4.122)=16.14, p<0.005, v=3.47$.

Table 12: Tests of between subject effects

\begin{tabular}{|c|c|c|c|c|}
\hline Source & Variables & $\mathrm{F}$ & $\mathrm{df}$ & $\mathrm{P}$ \\
\hline \multirow{3}{*}{ Co-Ex } & Equations & 20.29 & 1 & 0.000 \\
\cline { 2 - 5 } & In equations & 41.05 & 1 & 0.000 \\
\cline { 2 - 5 } & Powers & 44.82 & 1 & 0.000 \\
\cline { 2 - 5 } & Perimeters & 10.36 & 1 & 0.000 \\
\hline
\end{tabular}

The result (table-12) shows that the Art Integrated Learning in mathematics has statistically significant effects in all units considered for the study. With the score of 5 in Art Education, Equation ( $\mathrm{f}(1.125)=20.29$, in equation (f $(1.125)=41.05, \mathrm{p}<0.005$ powers $\mathrm{f}(11.125)=44.82$, $\mathrm{p}<0.005$, perimeter $(\mathrm{f}(1.125)=10.36, \mathrm{p}<0005)$.

\subsection{ART INTEGRATED LEARNING ACTIVITY FOR STUDENTS OF EXPERIMENTAL GROUP}

The students of Experimental Group involve in the following Art Integrated Learning activities.

Example 1: Students in the experimental group, while learning the unit "Equation", they paint a view out of a fairy- tale window. The window has two parts - the right and left - casement. It is going to help students to paint in balance. The right hand and left hand side of the casement have the same painting but one part is different which represent the unknown in equations (n).

The example of one student is shown in Fig.: 2 \& Fig.: 3. There are four planets in space on the left side of casement and on right side also. We can see same view but lunar eclipse occurs and covers some planets. Only two planets are visible now. How many of them are hidden under the moon? The answer is:

4 planet $=2$ planet $+n$

4 planet $-2=\mathrm{n}$

$\mathrm{n}=2$.

The students are able to get glued to the $\mathrm{n}$ (the moon) on to paintings. So it was lifted from bottom side, the equation written under moon is visible. In this experimental learning activity students observe their painting (equation) and are able to solve them at the end of the activity.

The example of the second student is about the shells on the beach, some of which are hidden by a ball. Written equation gives answer to the question: "How many shells are under ball? To check the answer ball is lifted up and the answer it is displayed.

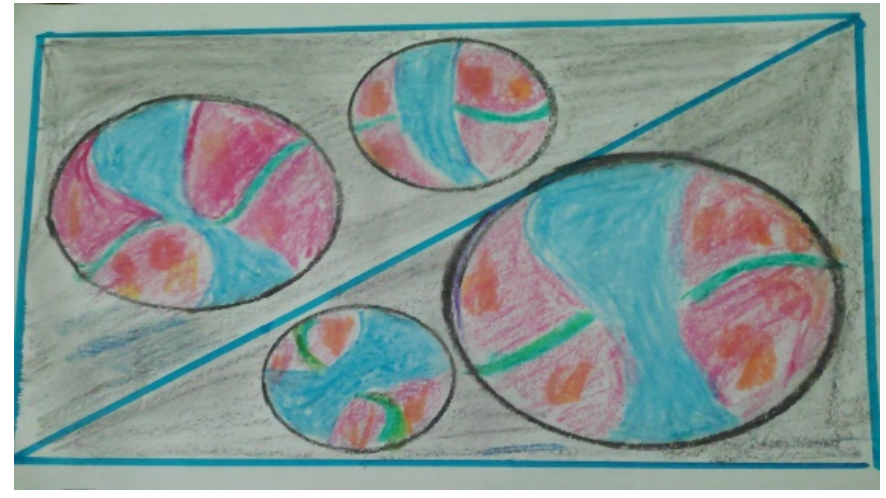

Figure 2: Painting by students

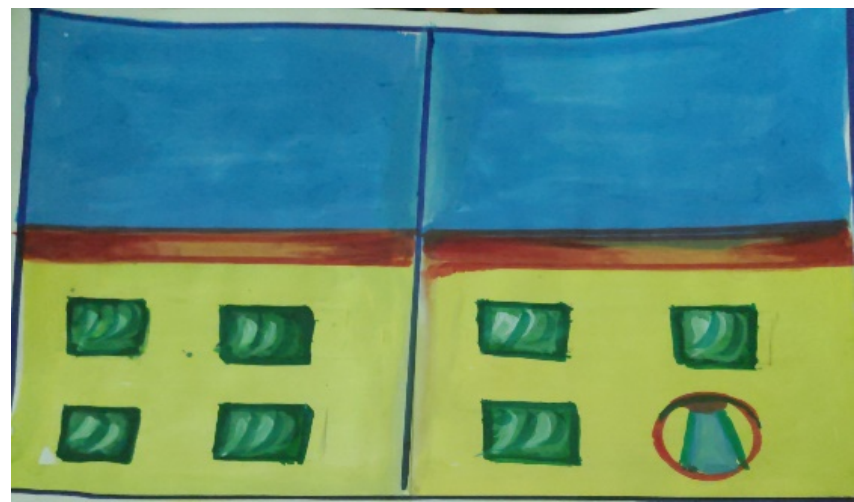

Figure 3: Painting by students 
Example 2: When students learn about powers, students prepare story about "small in smallest" and sketch it with colours.

Story 1: One of the students is shown the story about two spaces. Each space has two planets. Each country has two communities with two houses. This story represents the power of $2 . "$

Story 2: Second student is shown the story of farm. There are three hens. Each hen has three sheep. Each sheep has three lamps. This story represents power of 3.

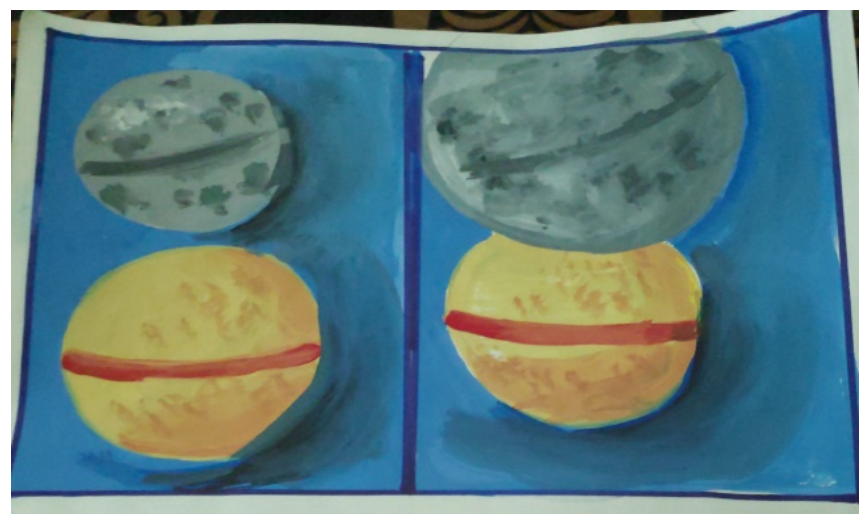

Figure 4: Painting by students

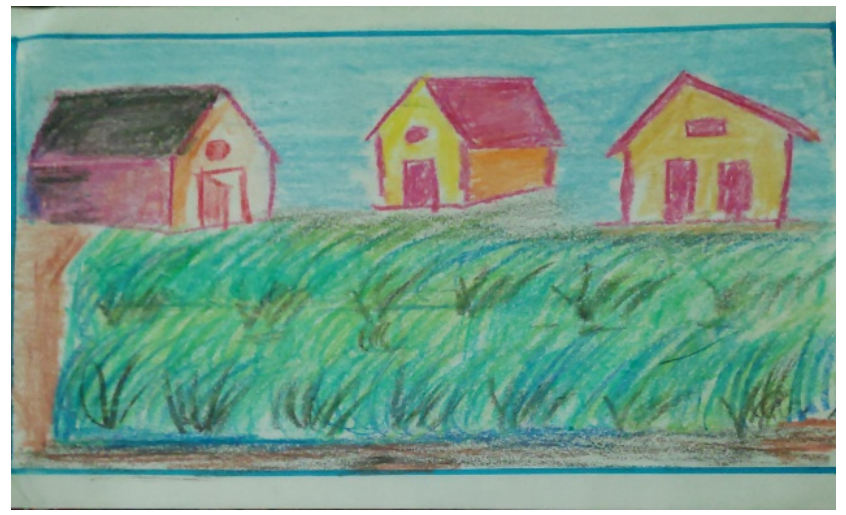

Figure 5: Painting by students

\section{CONCLUSION}

Art Integrated Learning activities for grade $\mathrm{V}$ mathematics foster academic achievement of the students in Experimental group when compared to the students of Control group.

The researcher also confirms hypothesis two. After achieving better performance in Mathematics, they also perform better in Art Education and in all four tests of MAT. the result shows improvement and has positive impact on them after teaching through Art Integrated Learning in some selected topics of mathematics.

This result is in line with Chapman (1998) Gatineau 2012.

The objective of Art Integrated Learning is to enhance student's participation in learning, make learning process joyful and improve students' performance in mathematics. Students learning in joyful learning environment at early stages. Preparation is hard for mathematics when it is integrated in higher classes. fields.

Students become more incline towards related fields such as physics, architecture, fashion design and other

To satisfy comprehensive need of today's rapidly changing society, students need to have knowledge as well as creativity.

\section{REFERENCES}

[1] Prashant Thote (2019) Experiential Learning: A Corns stone for Education in 21 ${ }^{\text {st }}$ Century Journal of Research Magma

[2] Prashant Thote (2019) "Experiential Learning: Model for Teaching Science in Grade Nine Students Achievement"

[3] Prashant Thote and R.K Sen (2019) "Experiential Learning: Inclusive Art Education for Joyful Learning", International Journal of Research Granthaalayah. (pages: 182,183).

[4] Prashant Thote, Experiential Learning: Art Integrated Learning in Science, Review of Research, Volume 8, Issue 5

[5] Prashant Thote and Gowri.S (2019) "Experiential Learning: Organizing the experiential learning in Mathematics", Review of Research, Volume 6, Issue 7.

[6] Prashant Thote and Gowri.S (2019) "Experiential Learning: Designing a Science Toy for Joyful Learning in Class-room", Review of Research, Volume 6, Issue 8. 
[7] Prashant Thote (2019) “Experiential Learning: Inclusive Art Education”, Review of Research, Volume 8, Issue 9.

[8] Prashant Thote and Gowri.S (2019) “Experiential Learning: Art Integrated Learning for Improving Students Learning", Review of Research, Volume 8, Issue 4.

[9] Prashant Thote and Gowri.S (2019) "Experiential Learning: Art Integrated Learning in Chemistry", Review of Research, Volume 8, Issue 6. 